\title{
Correlation of Vitamin D Status with Glycaemic Status of Individuals- A Cross Sectional Study in a Rural Tertiary Care Hospital of North Bengal, India
}

\author{
Souvik Konar ${ }^{1}$, Ritam Banerjee ${ }^{2}$ \\ ${ }^{1}$ Department of Biochemistry, NRS Medical College, Kolkata, West Bengal, India. ${ }^{2}$ Department of Biochemistry, \\ Coochbehar Government Medical College, Coochbehar, West Bengal, India.
}

\section{ABSTRACT}

\section{BACKGROUND}

Recent pandemic of vitamin D deficiency is co-existing with type II diabetes mellitus pandemic. Even in India, vitamin D insufficiency/deficiency is common among individuals with pre-diabetes. If correlation can be established between these two and risk of impaired glucose tolerance (IGT) or diabetes can be predicted based on serum vitamin D status, much early detection of pre-diabetes or diabetes will be possible and preventive measures can be taken. Not too many studies have been done in this context, especially in North Bengal region of West Bengal, India. We wanted to evaluate the correlation between vitamin D status and glycaemic status of individual and predict the risk of impaired glucose tolerance depending on vitamin $\mathrm{D}$, independent of other factors.

\section{METHODS}

After ethical clearance and informed consent, 430 study subjects were interviewed, examined, blood sample collected and tested. Data was entered in Microsoft Excel 2007 and analysed using appropriate software. Correlation and multinomial regression analysis were done.

\section{RESULTS}

Mean \pm SD of serum $25(\mathrm{OH})$ D level is found to be $21.53 \pm 7.06 \mathrm{ng} / \mathrm{ml}$ among a total of 430 study participants. $41.86 \%$ of participants were found to be with insufficient vitamin D status. Pearson's correlation between serum 25(OH) D level and post prandial blood sugar is found to be strongly negative while Spearman's correlation between vitamin D status and post prandial glycaemic status of individuals is found to be strongly positive. If vitamin D status changes from "Sufficient" to "Insufficient" or "Deficient", risk of IGT increases by 17 times and 16.3 times respectively.

\section{CONCLUSIONS}

Strong positive correlation exists between vitamin D status and glycaemic status of individuals. Estimation of $25(\mathrm{OH}) \mathrm{D}$ level may be used as a screening test for detection of risk of IGT.

\section{KEY WORDS}

Vitamin D, Diabetes Mellitus, Spearman's Rank Correlation Coefficient

\author{
Corresponding Author: \\ Dr. Ritam Banerjee, \\ 13/1, Subhaspally, \\ P.O., Siliguri Dist., \\ Darjeeling-734001, \\ West Bengal, India. \\ E-mail: mastermailritam@gmail.com \\ DOI: $10.14260 / j e m d s / 2020 / 57$ \\ Financial or Other Competing Interests: \\ None. \\ How to Cite This Article: \\ Konar S, Banerjee R. Correlation of vitamin \\ $D$ status with glycaemic status of \\ individuals- a cross sectional study in a \\ rural tertiary care hospital of North Bengal, \\ India. J. Evolution Med. Dent. Sci. \\ 2020;9(05):252-255, DOI: \\ $10.14260 / \mathrm{jemds} / 2020 / 57$
}

Submission 26-09-2019,

Peer Review 08-01-2020,

Acceptance 16-01-2020,

Published 03-02-2020. 


\section{BACKGROUND}

'Sunshine vitamin' i.e. Vitamin D, a secosteroid hormone, is essential for life in all higher organisms and is found as cholecalciferol (Vitamin D3) in vertebrates ${ }^{1}$. 25- hydroxy vitamin D [25(OH) D], hydroxylated and predominant form of the vitamin, plays many biological roles in calcium absorption, regulation of bone and mineral metabolism, muscle strengthening, cellular proliferation and differentiation, immune system modulation, inhibition of renin synthesis, erythropoiesis etc ${ }^{2}$. It also down-regulate the transcription of various proinflammatory cytokine genes (hallmark of type II diabetes mellitus) like IL-2, IL-12, Tumor Necrosis Factor- $\alpha$. And has a protective role on $\beta$ cell. 3,4,5,6 Deficiency of the said vitamin, emerged as a pandemic in recent year, leads to apoptosis of $\beta$ cell and production of cytokines (TNF- $\alpha$, IL-6), glucotoxicity and lipotoxicity, which are the major features among the patients of another pandemic of $21^{\text {st }}$ century i.e. T2DM.6,7,8,9

Co-existence of vitamin D deficiency and hyperglycemia are now well established as shown in studies from different parts of the world.10,11,12 Even in India, vitamin D insufficiency/deficiency is common among individuals with pre-diabetes ${ }^{13}$. Moreover, changing lifestyle, urbanization and modernization has led to possible reduction of people being exposed to direct sunlight and inadequate intake of dietary vitamin D. ${ }^{14}$ As a result, vitamin D deficiency or insufficiency prevails in all over the Indian subcontinent.15,16,17

As per available literatures not too many studies have been done in this context, especially in North Bengal region of West Bengal, India. So, this study was undertaken to find out the correlation between vitamin D status and glycaemic status of individual and determine the risk of impaired glucose tolerance depending on vitamin D status, independent of other factors.

\section{METHODS}

\section{Selection of Participants}

After obtaining ethical clearance from Institutional Ethics Committee, a cross sectional study was undertaken at North Bengal Medical College and Hospital from July 2016 to June 2017 amongst the Medicine OPD patients. Considering prevalence of impaired glucose tolerance to be $50 \%$, sample size for the study was estimated to be $430(p=50 \%, d=0.05$, $10 \%$ non-response). Every alternate attendee in Medicine OPD, of either sex, were approached for being a study subject. Those having frank diabetes, autoimmune diseases, chronic kidney \& liver disorders, morbidly obese, immunecompromised or taking drugs that can alter serum lipid profile, blood glucose and serum 25(OH) D levels, on hormone replacement therapy, substance abusers were excluded from the study.

\section{Data \& Blood Sample Collection}

After getting written informed consent from eligible \& willing subjects, they were interviewed using pre-structured, pretested questionnaire, anthropometric measurements were done for calculation of Body mass index (BMI) [Weight in $\mathrm{Kg}$ / Height in $\mathrm{m}^{2}$ ], and blood samples were collected in fluoride \& clotted vials. Serum was separated within 30-45 minutes of collection by centrifuge machine.

\section{Estimation of Blood Parameters}

Plasma glucose and Serum Calcium was estimated using Glucose Oxidase-Peroxidase (GOD/POD) Method and OCPC (oCresolphthalein Complexone) Method respectively. According to American Diabetes Association (2014), normal glucose tolerance was considered as a) Fasting plasma glucose level $<5.6 \mathrm{mmol} / \mathrm{l}(100 \mathrm{mg} / \mathrm{dl})$ and b) 2-hour post-prandial plasma glucose level $<7.8 \mathrm{mmol} / \mathrm{l}(140 \mathrm{mg} / \mathrm{dl})$. Subjects having fasting plasma glucose level between $5.6 \mathrm{mmol} / \mathrm{l} \& 6.9 \mathrm{mmol} / \mathrm{l}(100$ $\mathrm{mg} / \mathrm{dl} \& 125 \mathrm{mg} / \mathrm{dl}$ ) and 2-hour post-prandial plasma glucose level between $7.8 \mathrm{mmol} / \mathrm{l} \& 11 \mathrm{mmol} / \mathrm{l}(140 \mathrm{mg} / \mathrm{dl} \& 199$ $\mathrm{mg} / \mathrm{dl}$ ) were diagnosed as Impaired Fasting Glucose and Impaired Glucose Tolerance respectively ${ }^{18}$. Serum 25(OH) D levels were estimated by ELISA method and reference value is depicted in the below table.

\begin{tabular}{|c|c|}
\hline Level of Serum [25(OH)D] in $\mathrm{ng} / \mathrm{ml}$ & Status of Vitamin D \\
\hline$<20$ & Deficient \\
\hline $20-29$ & Insufficient \\
\hline $30-70$ & Sufficient \\
\hline$>70$ & Potential Toxicity \\
\hline \multicolumn{2}{|c|}{ Reference Values $^{19,20}$} \\
\hline
\end{tabular}

\section{Statistical Analysis}

Data so obtained by interview and laboratory investigations, are checked for completeness and entered in Microsoft Excel version 2007. Again, checked for consistency, were cleaned, copied in SPSS version 22.0 and codified. Pearson's, Spearman's rank correlation and multinomial logistic regression was done for analysis of data and results are depicted in tables and graphs. $p$ value $<0.05$ is considered as statistically significant.

\section{RESULTS}

It is found that mean \pm SD of age of study participants are 37.47 \pm 12.63 years with majority (36\%) belonging to 30 -39 years age group. Most of the participants are male (54.7\%) (Table 1). Mean \pm SD of serum $25(\mathrm{OH}) \mathrm{D}$ level is found to be $21.53 \pm 7.06$ $\mathrm{ng} / \mathrm{ml}$. sufficient vitamin D status is the lowest found (11.63\%) while Deficient status is the most (46.51\%) among the subjects. $41.86 \%$ participants are found to be with insufficient vitamin D status (Table 2). Regarding blood sugar parameters, mean \pm SD of PPBS level is found to be $160 \pm 29.4 \mathrm{md} / \mathrm{dl}$ while mean \pm SD of FBS level of subjects is $106.4 \pm 12.7 \mathrm{mg} / \mathrm{dl}$. Most of them (61.6\%) are found to be impaired glucose tolerant followed by normoglycemic (19.8\%) and diabetic (18.6\%) (Table 2). Pearson's correlation between serum $25(\mathrm{OH}) \mathrm{D}$ level and fasting blood sugar level is found to be (-ve) 0.524 while with that of post prandial blood sugar is (-ve) 0.492 . Both are statistically significant (Table 3).

Analysis between vitamin D status and post prandial glycaemic status shows IGT in $69.5 \%$ of the subjects with insufficient vitamin D status and in $65 \%$ with deficient vitamin D status. Prevalence of diabetes mellitus is much more (30\%) in vitamin D deficient subjects. Spearman's rank correlation coefficient between vitamin D status and glycaemic status of individual is found to be (+ve) 0.445 which is statistically significant (Table 4). 


\begin{tabular}{|c|c|c|}
\hline & Frequency & Percentage \\
\hline \multicolumn{3}{|c|}{ Age Group } \\
\hline $20-29$ & 120 & 27.9 \\
\hline $30-39$ & 155 & 36.0 \\
\hline $40-49$ & 100 & 23.3 \\
\hline $50-59$ & 25 & 5.8 \\
\hline $60-69$ & 10 & 2.3 \\
\hline $70-79$ & 20 & 4.7 \\
\hline Total & 430 \\
\hline Female & 195 & 100 \\
\hline Male & 235 & 45.3 \\
\hline Total & 430 \\
\hline Table 1. Distribution of Study Population \\
\hline \multicolumn{3}{|c|}{ According to Their Age \& Sex (n=430) } \\
\hline \multicolumn{2}{|c|}{}
\end{tabular}

\begin{tabular}{|c|c|c|}
\hline Vit D Status & Frequency & Percentage \\
\hline Deficient & 200 & 46.51 \\
\hline Insufficient & 180 & 41.86 \\
\hline Sufficient & 50 & 11.63 \\
\hline Total & 430 & 100.00 \\
\hline $\begin{array}{c}\text { Glycaemic status of the individuals as per post } \\
\text { prandial blood glucose }\end{array}$ & Frequency & Percentage \\
\hline DM & 80 & 18.6 \\
\hline IGT & 265 & 61.6 \\
\hline Normoglycemic & 85 & 19.8 \\
\hline Total & 430 & 100 \\
\hline \multicolumn{2}{|c|}{ Table 2. Distribution of Study Population According to Their } \\
Vitamin D Status and Post Prandial Glycaemic Status (n=430) \\
\hline \multicolumn{2}{|c}{}
\end{tabular}

\begin{tabular}{|c|c|c|}
\hline & Pearson Correlation & Significance Level \\
\hline FBS & -0.524 & $\mathrm{p}<0.05$ \\
\hline PPBS & -0.492 & $\mathrm{p}<0.05$ \\
\hline \multicolumn{2}{|c|}{ Table 3. Correlation of Serum 25(OH) D Level with } \\
Blood Sugar Parameters (n=430) \\
\hline
\end{tabular}

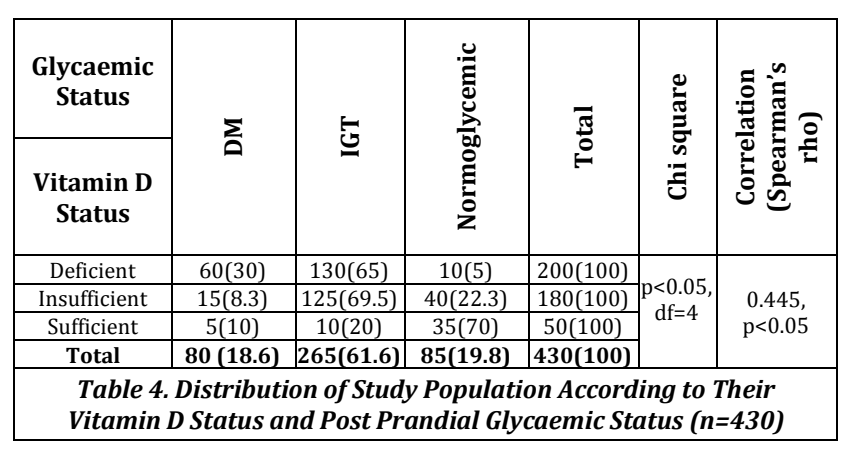

\begin{tabular}{|c|c|c|c|c|c|}
\hline \multicolumn{6}{|c|}{ Multinomial Regression Analysis } \\
\hline \multirow[t]{2}{*}{\begin{tabular}{|c|}
$\begin{array}{c}\text { Glycaemic } \\
\text { Status }\end{array}$ \\
\end{tabular}} & \multirow[t]{2}{*}{$\begin{array}{l}\text { Predictor } \\
\text { Variables } \\
\end{array}$} & \multirow[t]{2}{*}{$\begin{array}{c}\text { Adjusted } \\
\text { Odds Ratio }\end{array}$} & \multirow[t]{2}{*}{ Sig. } & \multicolumn{2}{|c|}{$\begin{array}{l}95 \% \text { Confidence } \\
\text { Interval for AOR }\end{array}$} \\
\hline & & & & $\begin{array}{l}\text { Lower } \\
\text { bound }\end{array}$ & $\begin{array}{l}\text { Upper } \\
\text { bound }\end{array}$ \\
\hline \multirow{6}{*}{ DM } & Age & 1.8 & 0.000 & 1.404 & 1.906 \\
\hline & Male & 9.0 & 0.002 & 2.073 & 12.342 \\
\hline & Female $^{\mathrm{b}}$ & 0 & & & \\
\hline & Vit D Deficient & 7.8 & 0.067 & 4.987 & 22.016 \\
\hline & Vit D Insufficient & 5.1 & 0.079 & 0.778 & 12.577 \\
\hline & Vit D Sufficient ${ }^{\mathrm{b}}$ & 0 & & & \\
\hline \multirow{6}{*}{ IGT } & Age & 1.7 & 0.000 & 1.354 & 1.893 \\
\hline & Male & 27.4 & 0.000 & 15.698 & 41.267 \\
\hline & Female $^{\mathrm{b}}$ & 0 & & & \\
\hline & Vit D Deficient & 16.3 & 0.005 & 7.956 & 19.073 \\
\hline & Vit D Insufficient & 17.0 & 0.000 & 4.085 & 32.984 \\
\hline & Vit D Sufficient ${ }^{\mathrm{b}}$ & 0 & & & \\
\hline \multicolumn{6}{|c|}{ a. The reference category for dependent variable is: Normoglycemic. } \\
\hline \multicolumn{6}{|c|}{ b. This parameter is set to zero because it is redundant. } \\
\hline \multicolumn{6}{|c|}{$\begin{array}{l}\text { Table 5. Multinomial Regression Analysis Showing Risk } \\
\text { of DM \& IGT }(n=430)\end{array}$} \\
\hline
\end{tabular}

In multinomial regression analysis, taking 'normoglycemic' as reference category for dependent variable and adjusted for other independent variables, it is found that, with change in vitamin D status from "Sufficient" to "Insufficient" and "Deficient", risk of IGT increases by 17 times and 16.3 times respectively and both of the findings are statistically significant. Change in vitamin D status in the same manner, as previously mentioned, increases the risk of Diabetes mellitus by 5.1 times and 7.8 times respectively but the findings are not statistically significant. Statistically significant finding of males being at 27.4 times higher risk of developing IGT than females are also found. With one-year increase in age risk of IGT increases by 1.7 times (Table 5).

\section{DISCUSSION}

In this observational study at North Bengal Medical College and Hospital from July 2016 to June 2017 amongst the Medicine OPD patients, it is found that majority of the study population belonged to age group 30-39 years (36\%) followed by $20-29$ years age group (27.9\%). Most of them were male (54.7\%). 46.51\% study participants are found to be vitamin D deficient while $41.86 \%$ are vitamin D insufficient. A study on Asian subjects done by Soo Lim et $\mathrm{al}^{21}$. showed that $51.6 \%$ had vitamin D insufficiency. Another study in North Indian community had showed that $75.8 \%$ participants were vitamin D deficient. ${ }^{19}$ Differences in ethnicity, varying degree of exposure to sunlight may play a role behind such diverse findings. Most of the present study population (61.6\%) are found to be impaired glucose tolerant followed by normoglycemic (19.8\%). In a study conducted at D. Y. Patil University, School of Medicine Bajaj AH et al had found 51.38\% subjects were diabetic and $48.61 \%$ were non-diabetic. However, they had considered DM based on fasting blood sugar while the present study relies on post prandial blood sugar level. Statistically significant, strong negative correlation is found between serum 25(OH) D levels and both fasting and post prandial blood sugar levels. That means that with decrease in serum $25(\mathrm{OH})$ D level, both FBS \& PPBS levels will increase. Similar findings were showed in a study done by Kirubhakaran Kanakaraju et al in Tamilnadu

$69.5 \%$ of the study population having insufficient vitamin D status has IGT while 30\% with vitamin D deficiency has DM. Association between vitamin D status and glycaemic status is found to be statistically significant by chi-square test. The study of Bajaj AH had found that $33.3 \%$ of vitamin D deficient subjects were diabetic. ${ }^{22}$ The finding lies in close proximity of the present study. Again, statistically significant, strong positive correlation is found between vitamin $\mathrm{D}$ status and glycaemic status of individual which means that with deterioration in vitamin D status, glycaemic status will also deteriorate from normoglycemic to DM through IGT. Study finding of Kant et al. indirectly supports this where they showed that vitamin D deficiency is inversely related to glycaemic control (HbA1c) of individual. ${ }^{23}$

In multinomial regression analysis, taking 'normoglycemic' as reference category for dependent variable it is found that, with deteriorating vitamin D status, risk of IGT increases many times and that is independent of all other predictor variables. Robert Scragg et al had concluded in their study that IGT is associated with low serum concentrations of $[25(\mathrm{OH}) \mathrm{D}] .{ }^{24}$ Males are at higher risk of developing IGT than females. 


\section{CONCLUSIONS}

Vitamin D status is one of the determining factors of glycaemic status of individuals. With increasing burden of diabetes, it will always be better if it can be detected much early or even in prediabetes period so that corrective measures can be taken. Serum 25(OH) D level estimation may be used as a screening for the risk of IGT. However, to establish a causal association between vitamin D status and glycaemic status of individual, large scale prospective, multi-centric studies should be conducted.

\section{ACKNOWLEDGEMENT}

Authors thank the study participants, health staff, laboratory technicians and college authorities for their support.

\section{REFERENCES}

[1] Peterson CA, Tosh AK, Belanchia AM. Vitamin D insufficiency and insulin resistance in obese adolescents. Ther Adv Endocrinol Metab 2014;5(6):166-89.

[2] Shenoy V, Datta P, Prabhu K, et al. Association between Vitamin D, fasting blood glucose, HbA1c and fasting lipid profile in Euglycemic individuals. Journal of Research in Diabetes 2014;2014:929743.

[3] Hotamisligil GS, Arner P, Caro JF, et al. Increased adipose tissue expression of tumour necrosis factor-alpha in human obesity and insulin resistance. J Clin Invest 1995;95(5):2409-15.

[4] Pittas AG, Dawson-Hughes B. Vitamin D and Diabetes. J Steroid Biochem Mol Biol 2010;121(1-2):425-9.

[5] Schleithoff SS, Zittermann A, Tenderich G, et al. Vitamin D supplementation improves cytokine profiles in patients with congestive heart failure: a double-blind, randomized, placebo-controlled trial. Am J Clin Nutr 2006;83(4):75449.

[6] West IC. Radicals and oxidative stress in diabetes. Diabetic Med 2000;17(3):171-80.

[7] Van Schoor NM, Lips P. Worldwide Vitamin D status. Best Pract Res Clin Endocrinol Metab 2011;25(4):671-80.

[8] Mithal A, Wahl DA, Bonjour JP, et al. Global vitamin D status and determinants of hypovitaminosis D. Osteoporos Int 2009;20(11):1807-20.

[9] Van der Meer IM, Middelkoop BJ, Boeke AJ, et al. Prevalence of vitamin D deficiency among Turkish, Moroccan, Indian and sub-Sahara African populations in Europe and their countries of origin: an overview. Osteoporos Int 2011;22(4):1009-21.

[10] Kanakaraju K, Ranganathan RS, Shankar R. Correlation of vitamin $\mathrm{D}$ levels and the blood sugar parameters among the patients with type 2 diabetes mellitus. International Journal of Contemporary Medical Research 2017;4(4):844-7.
[11] Nayak SB, Ramnanansingh TG. Evaluation of vitamin D relationship with type 2 diabetes and systolic blood pressure. BMJ Open Diabetes Research and Care 2016;4(1):e000285.

[12] Anwar T, Rahman MM, Mollah FH, et al. Association of serum vitamin $\mathrm{D}$ with newly diagnosed type 2 diabetes mellitus. Bangabandhu Sheikh Mujib Med Univ J 2018;11:99-101.

[13] Dutta D, Maisnam I, Shrivastava A, et al. Serum Vitamin-D predicts insulin resistance in individuals with prediabetes. Indian J Med Res 2013;138(6):853-60.

[14] Srinath KM, Shashidhara KC, Rajeev RG, et al. Pattern of vitamin D status in prediabetic individuals: a case control study at tertiary hospital in South India. Int J Res Med Sci 2016;4(4):1010-5.

[15] Gandhe MB, Velu VK, Shyamini SR, et al. Circulating 25hydroxyvitamin $\mathrm{D}$ status in apparently healthy adolescents and its association with body mass index in Puducherry population. Indian J Child Health 2016;3(2):110-5.

[16] Ritu G, Gupta A. Vitamin D deficiency in India: prevalence, causalities and interventions. Nutrients 2014;6(2):72975.

[17] Looned K, Banerjee A, Landge JA, et al. Intergenerational decline in Vitamin D status: a cross-sectional study among medical students and their teachers. Int J Nutr Pharmacol Neurol Dis 2017;7(1):12-7.

[18] American Diabetes Association. Standards of medical care in diabetes--2014. Diabetes Care 2014;37(Supplement 1):S14-S80.

[19] Holick MF. Vitamin D deficiency. N Engl J Med 2007;357(3):266-81.

[20] Braun TR, Been LF, Blackett PR, et al. Vitamin D deficiency and cardio-metabolic risk in a north Indian community with highly prevalent type 2 diabetes. J Diabetes Metab 2012;3: doi: 10.4172/2155-6156.1000213.

[21] Lim S, Kim MJ, Choi SH, et al. Association of vitamin D deficiency with incidence of type 2 diabetes in high-risk Asian subjects. The American Journal of Clinical Nutrition 2013;97(3):524-30.

[22] Bajaj A, Gadre S, Sukumaran S, et al. Correlation of Vitamin D deficiency with Type 2 diabetes and metabolic traits in the Indian population. Int J Basic Clin Pharmacol 2015;4(6):1224-7.

[23] Kant R, Chandra R, Arzumanyan H, et al. Prevalence of vitamin D deficiency and association with glycemic control in patients with type 2 diabetes mellitus: a retrospective analysis. Sch J App Med 2010;26(1)

[24]Scragg R, Holdaway I, Singh V, et al. Serum 25hydroxyvitamin D3 levels decreased in impaired glucose tolerance and diabetes mellitus. Diabetes Research and Clinical Practice 1995;27(3):181-8. 